\title{
The TAT Protein Transduction Domain Enhances the Neuroprotective Effect of Glial-Cell-Line-Derived Neurotrophic Factor after Optic Nerve Transection
}

\author{
Ülkan Kilic Ertugrul Kilic Gunnar P.H. Dietz Mathias Bähr \\ Department of Neurology, Georg August University Göttingen, Göttingen, Germany
}

\author{
Key Words \\ Apoptosis · Glial-cell-line-derived neurotrophic factor · \\ Neurodegeneration - Neurotrophin - Optic nerve \\ axotomy · Protein transduction domain · Retinal \\ ganglion cells · TAT fusion protein - Trojan horse \\ peptide
}

\begin{abstract}
Glial-cell-line-derived neurotrophic factor (GDNF) acts as a potent survival factor for many neuronal populations, including retinal ganglion cells (RGC), indicating a potential therapeutic role of GDNF for neurological disorders. To enhance the tissue distribution and applicability of the neurotrophin, we linked it to a protein transduction domain derived from the HIV TAT protein and tested it in a well-established model for traumatic injury in the CNS: After optic nerve axotomy, the number of surviving RGCs was significantly increased in mice injected with TAT-GDNF on days $0,3,7$, and 10 after surgery compared with GDNF- or PBS-injected animals. Moreover, TAT-GDNF reduced the number of activated caspase-3positive cells. These results show that the neuroprotective effect of substances like neurotrophins may be enhanced by linking them to a domain that has been shown to mediate efficient transduction across biological mem-
\end{abstract} branes.

Copyright @ 2004 S. Karger AG, Basel

\begin{tabular}{ll}
\hline KARGER & ( ) 2004 S. Karger AG, Basel \\
1660-2854/04/0011-0044\$21.00/0 \\
$\begin{array}{l}\text { Fax +4161306 1234 } \\
\begin{array}{l}\text { E-Mail karger@karger.ch } \\
\text { www.karger.com }\end{array}\end{array}$ & $\begin{array}{l}\text { Accessible online at: } \\
\text { www.karger.com/ndd }\end{array}$
\end{tabular}

In the recent years, a large number of peptides with neuroprotective or anti-apoptotic features has been characterized. It was suggested that application of neuroprotective proteins might be a favorable approach to treat neurodegenerative diseases. However, delivery of such proteins into tissues and across the blood-brain or bloodretina barrier is limited by the size of the respective proteins. The protein transduction domain derived from the human immunodeficiency virus-1 TAT protein is able to deliver biologically active proteins across these barriers in vivo $[1,2]$.

Glial-cell-line-derived neurotrophic factor (GDNF), a member of the transforming growth factor- $\beta$ superfamily, is a potent neurotrophic factor that promotes the survival and morphological differentiation of dopaminergic neurons [3-5], motor neurons [6, 7] and retinal ganglion cells (RGC) $[8,9]$. The protective effects of externally applied GDNF have been well established in different models of neurodegenerative diseases [10-13].

The retinotectal projection is a well-defined experimental system, which enables to study molecular mechanisms of de- and regeneration of injured neurons of the central nervous system in vivo. In adult mammals, transection of the optic nerve $(\mathrm{ON})$ triggers a highly coordinated response of injury-associated gene expression in lesioned RGC somata, which results in the activation of apoptotic cascades and finally leads to cell death [for

\footnotetext{
Prof. Dr. med. Mathias Bähr

Zentrum Neurologische Medizin, Universitätsklinikum

Georg-August-Universität Göttingen, Robert-Koch-Strasse 40

DE-37075 Göttingen (Germany)

Tel. +49551 396603, Fax +49551 398405, E-Mail mbaehr@gwdg.de
} 
review, see ref. 14-18]. Transection of the $\mathrm{ON}$ has also been successfully used to study the efficacy of various neuroprotective agents $[17,19]$.

In this study, the distribution of the TAT-mediated GDNF transduction was examined in different tissues after intravitreal administration of TAT-GDNF protein. In the second part of this study, the neuroprotective effects of TAT-GDNF fusion protein on the survival of axotomized RGC was evaluated and compared with GDNF- and PBS-treated animals after intravitreal administration of the respective factors.

\section{Materials and Methods}

\section{Recombinant Protein Expression and Purification}

The GDNF-coding sequence was polymerase chain reaction amplified from rat whole brain cDNA with the following primers: 5'ATTATACCATGGCCAG CCCAGAGAATTCCAGA-3' and 5'TTATACTCGAGTCAGATACATCCACACCG-3'. Purified polymerase-chain-reaction-amplified fragments were cloned into the $N c o$ I and EcoRI restriction enzyme sites of the pTAT-hemagglutinin (pTAT-HA) expression vector, which was kindly provided by Dr. Steven F. Dowdy (San Diego, Calif., USA). Recombinant TATGDNF expression and purification were performed as described [20]. Briefly, the TAT-GDNF plasmid was transformed into BL21 (DE3) pLysS bacteria. A 200-ml LB ampicillin overnight culture of TAT-GDNF was placed into 1 liter of LB ampicillin and incubated for $6 \mathrm{~h}$ at $37^{\circ} \mathrm{C}$ with shaking. In order to prepare the denatured TATGDNF fusion protein, the bacterial pellet was washed with PBS, and resuspended in $10 \mathrm{ml}$ buffer $\mathrm{Z}(8 M$ urea, $100 \mathrm{~m} M \mathrm{NaCl}$ and $20 \mathrm{~m} M$ HEPES, $\mathrm{pH}$ 8.0). The suspension was sonicated on ice with 4 cycles of $15 \mathrm{~s}$ on and $15 \mathrm{~s}$ off. The sonicate was clarified by centrifugation at $16,000 \mathrm{~g}$ for $15 \mathrm{~min}$ at $4^{\circ} \mathrm{C}$. The supernatant was then adjusted to a concentration of $10 \mathrm{~m} M$ imidazole and applied at room temperature to a preequilibrated Ni-NTA column (Qiagen, Hilden, Germany). The column was then washed with $10 \mathrm{~m} M$ imidazole in buffer $Z$. The enriched fusion protein was eluted from Ni-NTA column by stepwise application of 100, 250 and $500 \mathrm{~m} M$ imidazole. The purified fractions were pooled and desalted on PD-10 columns (Amersham Pharmacia, Uppsala, Sweden). The protein concentration and purity in each protein fraction was quantified using a Coomassie stain following separation by SDS-PAGE and comparison to bovine serum albumin as the standard. Western blotting using the anti-hemagglutinin (HA) antibody (Sigma-Aldrich, Germany) confirmed the protein identity. Goat anti-rabbit horse radish peroxidase antibodies were obtained from Santa Cruz Biotechnology (Calif., USA).

\section{Experimental Groups}

All experimental procedures were carried out according to the $\mathrm{NIH}$ guidelines for the care and use of laboratory animals with permission of local government authorities. Adult male C57BL/6J mice (Charles River Laboratory, Sulzfeld, Germany), weighing 21-25 g, were assigned to the following experiments and groups: (I) The animals received intravitreal injections of $0.75 \mu 1$ of $0.1 \mathrm{M}$ PBS, either with 5 pmol TAT-GDNF, GDNF or no protein. These animals were not submitted to ON axotomy and sacrificed $1(n=2), 24(n=2)$, $48(\mathrm{n}=2)$ and $72 \mathrm{~h}(\mathrm{n}=2)$ after injection. (II) RGC were pre-labeled with 1,1'-dioctadecyl-3,3,3',3'-tetramethyl indocarbocyanine perchlorate (Di-I) via the superior colliculus prior to axotomy and (a) PBS treated $(n=5)$; (b) TAT-GDNF treated $(n=5)$ or (c) GDNF protein (carrier free, R\&D Systems, Minneapolis, Minn., USA) treated $(n=6)$. (III) To generate transverse sections for caspase-3 immunocytochemistry, mice were (a) PBS treated $(n=6)$ or $(b)$ TATGDNF treated $(n=5)$. Proteins and PBS were applied intravitreally in groups IIa-c and IIIa, b. All animals were sacrificed 14 days after ON axotomy.

\section{Retrograde Labeling of RGCs and ON Axotomy}

Animals were anesthetized by intraperitoneal injection of $7 \%$ chloral hydrate. To detect RGCs, cell bodies were labeled retrogradely with the fluorescent tracer Di-I (Molecular Probes, Oregon, USA). To that end, the superior colliculi were exposed by drilling a burr hole into the pericranium $0.7 \mathrm{~mm}$ lateral to the sagittal suture and $3 \mathrm{~mm}$ posterior to the bregma. A Hamilton syringe was inserted $2.0 \mathrm{~mm}$ beneath the surface of the brain, and $3 \mu \mathrm{l}$ of Di-I ( $5 \% \mathrm{Di}-\mathrm{I}$, in $50 \%$ dimethyl sulfoxide, infusion rate $0.7 \mu \mathrm{l} / \mathrm{min}$ ) was injected stereotactically into both superior colliculi. After infusion, the injection needle remained inside the tissue for 2 min to prevent Di-I diffusion along the needle track, before the syringe was withdrawn, and wounds were closed with a suture.

Four days after labeling, mice were anesthetized with 7\% chloral hydrate. After skin incision close to the superior orbital rim, the right orbita was opened, leaving the supraorbital vein intact, and the lacrimal gland was resected subtotally. After spreading the superior extraocular muscles, the right $\mathrm{ON}$ was transected under microscopical control approximately $0.5 \mathrm{~mm}$ distant to the posterior pole of the eye, taking care not to damage the retinal blood vessels. The wounds were sutured, and the retinal blood supply was verified by fundoscopy [21].

\section{Administration of Proteins}

For intraocular injection of TAT-GDNF, GDNF or PBS on days $0,3,7$, and 10 after ON axotomy, animals were anesthetized with diethylether. Using a glass microelectrode $(\sim 50 \mu \mathrm{m}$, outer diameter of the tip of microelectrode), TAT-GDNF, GDNF and PBS were injected into the vitreous space puncturing the eye at the corneasclera junction under a microscope to avoid damage to the lens [22].

\section{Tissue Processing}

In the first series of experiments, 14 days after ON transection, mice were sacrificed by an overdose of chloral hydrate, and both eyes were removed. The retinas were dissected, flat mounted on glass slides and fixed in 4\% paraformaldehyde in $0.1 \mathrm{M}$ PBS for $30 \mathrm{~min}$. Surviving RGCs were evaluated by fluorescence microscopy using a rhodamine filter $(546 / 590 \mathrm{~nm})$. RGC densities were determined by counting tracer-labeled RGCs in 12 distinct areas of $62,500 \mu \mathrm{m}^{2}$ each (three areas per retinal quadrant at three different retinal eccentricities of $1 / 6,3 / 6$ and $5 / 6$ of the retinal radius, respectively) [22, 23].

For caspase- 3 staining, eyes were fixed in $4 \%$ paraformaldehyde, fully impregnated with $30 \%$ sucrose at $4{ }^{\circ} \mathrm{C}$ and embedded in TissueTek (Shandon, Pittsburg, Pa., USA). Retinas were snap-frozen. Sixteen-micrometer cryostat retinal sections were air-dried at $37^{\circ} \mathrm{C}$ and stored at $-80^{\circ} \mathrm{C}$ until staining for activated caspase-3. The left eye served as an internal control in individual animals. 

intravitreal administration by the anti- HA antibody. The recombinant protein includes an HA tag. Immunhistochemistry was performed 1 (a-c), 24 (d-f) and $48 \mathrm{~h}(\mathbf{g}-\mathbf{i})$ after intravitreal administration of TAT-GDNF and after no administration (j-I). $\mathbf{a}, \mathbf{d}, \mathbf{g}, \mathbf{j}$ Immunohistochemistry using the HA antibody. $\mathbf{b}, \mathbf{e}, \mathbf{h}, \mathbf{k}$ Histomorphology of the brain regions in $\mathbf{a}, \mathbf{d}, \mathbf{g}, \mathbf{j}$, respectively, is depicted by DAPI staining. c, $\mathbf{f}, \mathbf{i}, \mathbf{I}$ Photomicrographs $\mathbf{a}, \mathbf{d}, \mathbf{g}, \mathbf{j}$ and $\mathbf{b}$, $\mathbf{e , ~} \mathbf{h}, \mathbf{k}$ are superimposed. $\mathrm{Bar}=50 \mu \mathrm{m}$.
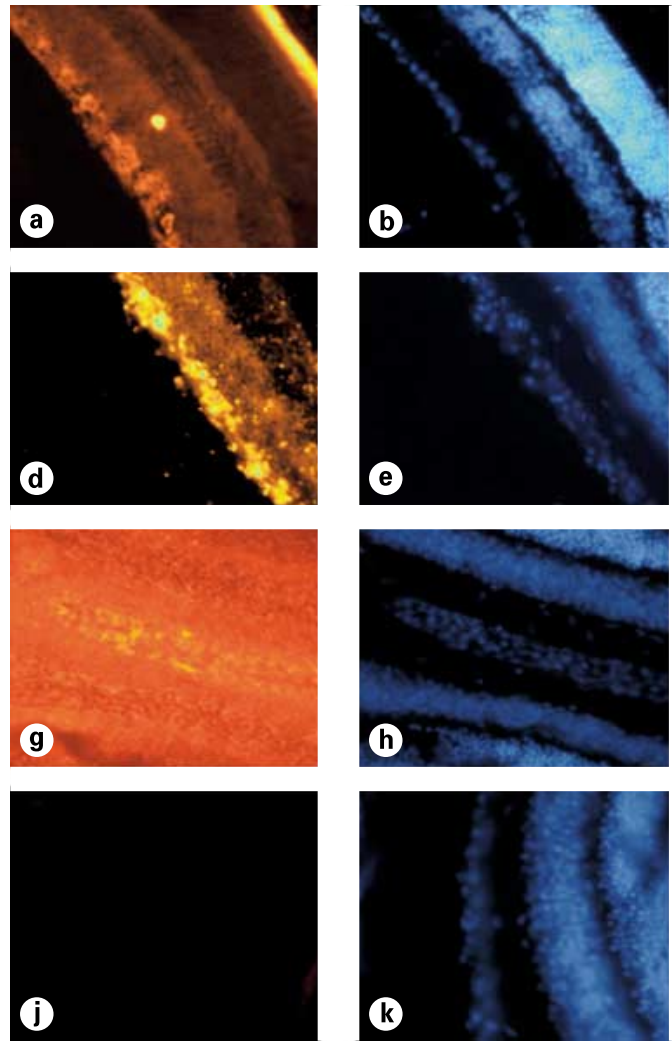
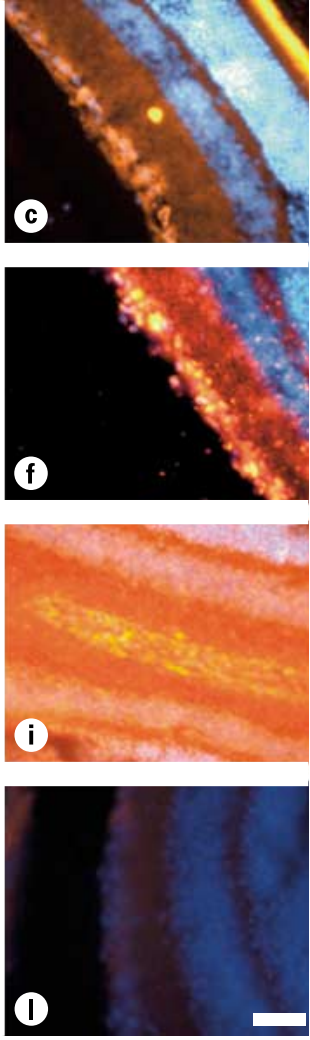

Immunocytochemical Analysis of Tissue GDNF Content and Caspase-3 Activation

For analysis of tissue GDNF content, tissues were perfusion fixed in $4 \%$ paraformaldehyde in $0.1 M$ PBS ( $\mathrm{pH} 7.4)$. Tissues were postfixed for $4 \mathrm{~h}$ in $4 \%$ paraformaldehyde/0.1 $M$ PBS and immersed in $30 \%$ sucrose $/ 0.1 \mathrm{M}$ PBS at $4{ }^{\circ} \mathrm{C}$ overnight. Sagittal $16-\mu \mathrm{m}$ sections were cut on a cryostat. For analysis of activated caspase-3, retinas were frozen on dry ice and cut into $16-\mu \mathrm{m}$ coronal cryostat sections, which were immersion fixed in $4 \%$ paraformaldehyde/ $0.1 \mathrm{M}$ PBS for 8 min at $4^{\circ} \mathrm{C}$.

Tissue sections were washed three times for $5 \mathrm{~min}$ in $0.1 \mathrm{M}$ PBS and immersed for $30 \mathrm{~min}$ in $0.1 \mathrm{M}$ PBS containing $0.3 \%$ Triton (PBS-T) and 10\% normal goat serum. After three further rinses in $0.1 M$ PBS, sections were incubated overnight at $4{ }^{\circ} \mathrm{C}$ with PBS-T containing $2 \%$ normal goat serum and polyclonal rabbit antibody against HA (Sigma, St. Louis, Mo., USA; diluted 1:250) or p20 fragment of caspase-3 (CM-1 antibody, Idun Pharmaceuticals, diluted 1:500). The next day, sections were washed three times for $5 \mathrm{~min}$ in $0.1 M$ PBS and incubated for $2 \mathrm{~h}$ with $0.1 M \mathrm{PBS} / 10 \%$ normal goat serum containing anti-rabbit $\mathrm{Cy} 3$ antibody, diluted 1:250. After three further rinses in PBS, sections were counterstained with DAPI (4',6 diaminido-2-phenylindoledihydrochloride, Merck KGaA, Darmstadt, Germany), coverslipped with Mowiol and evaluated under epifluorescence using appropriate filters.

RGCs positive for active caspase- 3 were detected under epifluorescence with a Zeiss microscope using appropriate filters on transverse sections (PBS, $n=6$; TAT-GDNF, $n=5$; one section each of 6 or 5 animals, respectively).
Statistics

All values are given as means \pm SD. Differences between groups were compared using one-way ANOVA followed by the least-significant difference test. $\mathrm{p}$ values less than 0.05 were considered to indicate statistical significance. Independent $t$ test was used for caspase-3 analysis.

\section{Results}

Tissue Transduction after Intravitreal Administration of $T A T-G D N F$

Experiments using GDNF antibodies showed no detectable GDNF $1 \mathrm{~h}$ after intravitreal administration of native GDNF protein (not shown). On the other hand, TAT-GDNF was detected 1 (fig. 1a-c), 24 (fig. 1d-f) and $48 \mathrm{~h}$ (fig. 1g-i) after intravitreal administration of TATGDNF by the HA antibody. No protein was detectable $72 \mathrm{~h}$ after administration of TAT-GDNF (not shown) and in uninjected control retinas (fig. $1 \mathrm{j}-1$ ). 

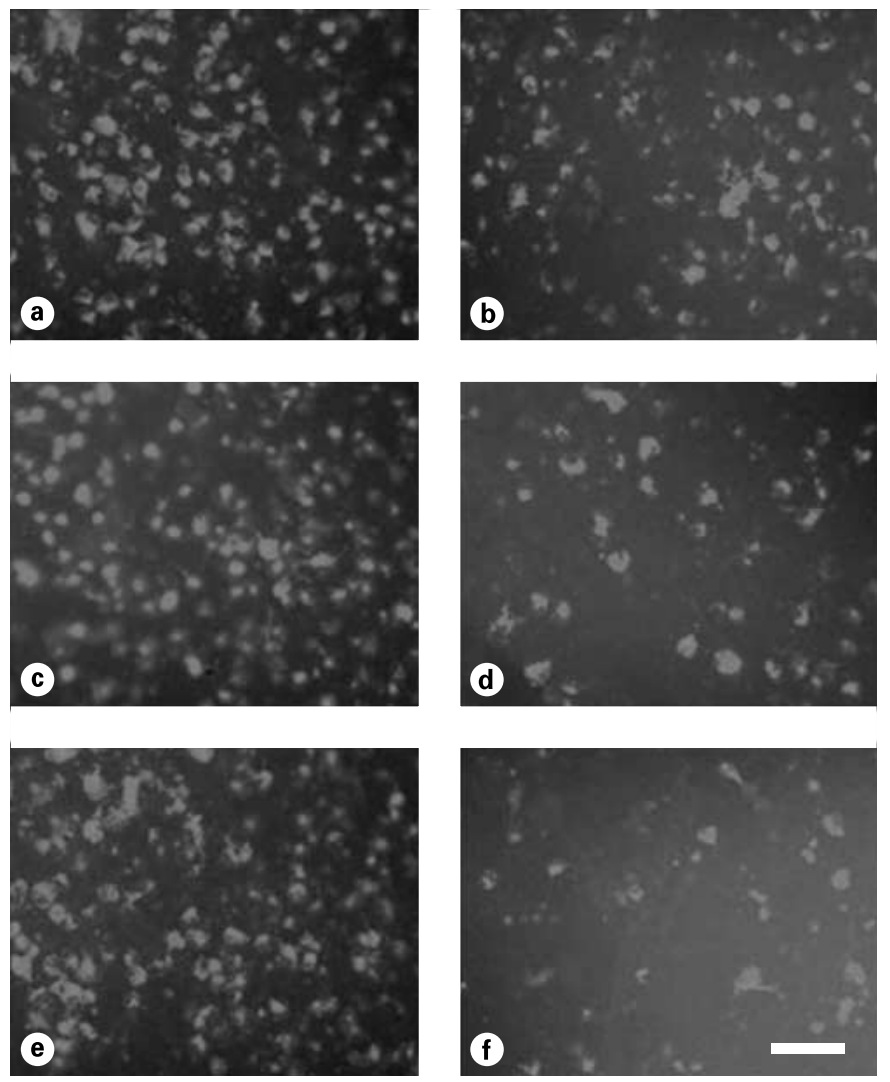

Fig. 2. TAT-GDNF increases RGC survival 14 days after ON axotomy. Fluorescent pictures of whole-mount retina, retrogradely labeled with the lipophilic tracer Di-I, prepared from unoperated control eyes $(\mathbf{a}, \mathbf{c}, \mathbf{e})$ or eyes prepared 14 days after axotomy and injected with TAT-GDNF (a, b), GDNF (c, d) and PBS $(\mathbf{e}, \mathbf{f})$. Images taken at $3 / 6$ of the retinal radius. $\mathrm{Bar}=50 \mu \mathrm{m}$.

\section{Effects of TAT-GDNF on RGC Survival after ON Axotomy}

14 days after ON axotomy, higher numbers of RGC survived in retinas that had received TAT-GDNF (fig. 2a, b), as compared to those that had received native GDNF (fig. 2c, d) or just PBS (fig. 2e, f). Cell counts of Di-I-identified RGCs from axotomized animals are presented in figure $3 \mathrm{a}$ and $\mathrm{b}$. RGC survival was significantly improved in the GDNF ( $26 \pm 7 \%$ surviving RGC) and TAT-GDNF (35 $\pm 8 \%$ surviving RGC) intravitreally injected animals compared with PBS-treated animals $(16 \pm 3 \%)$. Compared with GDNF-treated animals, the number of surviving neurons was significantly increased in the TATGDNF-treated animals 14 days after axotomy (fig. 3a).

RGC rescue by intraocular TAT-GDNF and GDNF was dependent on retinal eccentricity (fig. 3b). Referring to the numbers of RGCs that would die without protein
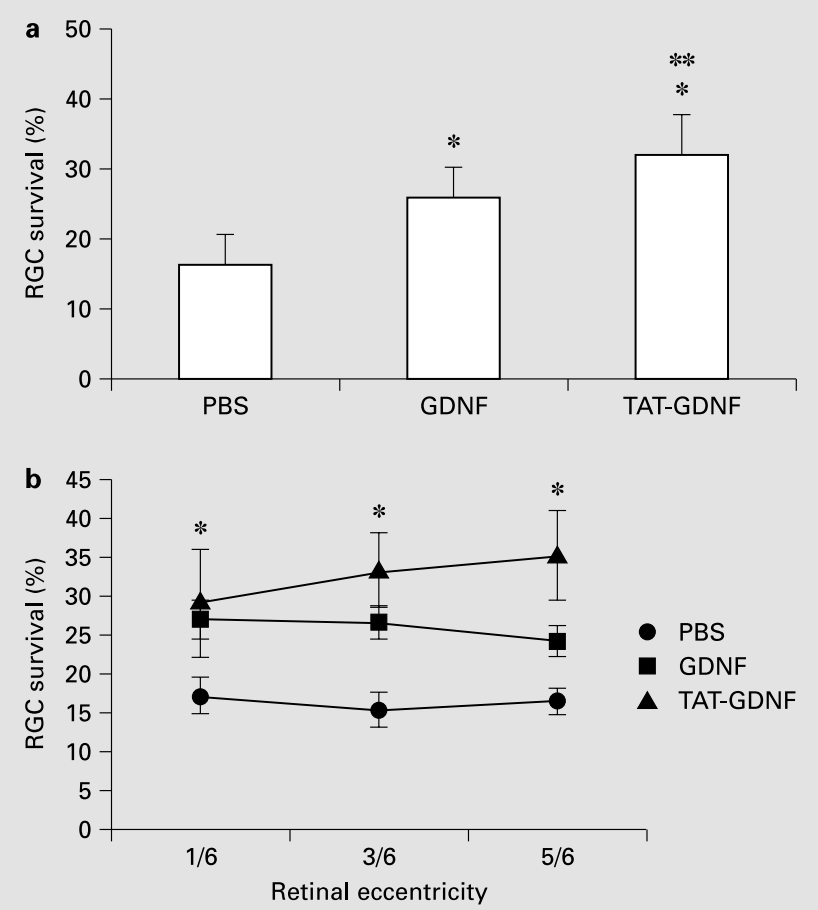

Fig. 3. RGCs surviving 14 days after axotomy, given as fractions of cell numbers in non-axotomized eyes (a). Areas were counted separately at $-1 / 6,1 / 2$ and $5 / 6$ of the retinal radius as indicated (b). Data are given as means \pm SD. $* \mathrm{p}<0.05$ compared with PBS-treated mice. ${ }^{* *} \mathrm{p}<0.05$ compared with GDNF-treated mice.

treatment, both GDNF and TAT-GDNF rescued 1.5-2 times more RGCs at $3 / 6$ and $5 / 6$ of the retinal radius as compared to the inner circumferences. Native GDNF demonstrated only a significant protection at $3 / 6$ of the retinal radius compared with PBS-treated animals, while TAT-GDNF was protective throughout the retina (fig. 3b).

\section{TAT-GDNF Reduces the Number of RGC Positive for Activated Caspase-3}

To show that TAT-GDNF acts by inhibiting apoptosis in axotomized RGC, we performed immunohistochemistry against activated caspase- 3 on retinal sections and counted the number of positive cells. The number of cells that showed activation of caspase-3 was significantly reduced in TAT-GDNF $(2.93 \pm 1.5)$ compared with PBStreated control animals $(6.33 \pm 1.7)$ (fig. 4). 


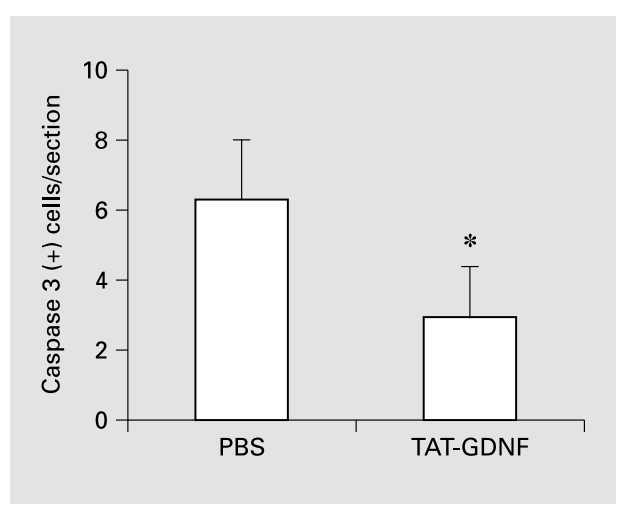

Fig. 4. Average number of caspase-3-positive cells per $16-\mu \mathrm{m}$ thick section in the retina of mice subjected to ON axotomy and treated with PBS $(n=6)$ or TAT-GDNF $(n=5)$ as shown by immunocytochemistry. Data are given as means \pm SD. ${ }^{*} \mathrm{p}<0.05$ compared with PBS-treated mice.

\section{Discussion}

In previous reports $[24,25]$, we have demonstrated TAT-mediated delivery of Bcl-X $\mathrm{L}$, GFP and GDNF proteins into brain parenchyma $4 \mathrm{~h}$ after intravascular administration and neuroprotective effects of TAT-mediated proteins after intravenous administration. TATGDNF and TAT-Bcl- $\mathrm{X}_{\mathrm{L}}$ significantly reduced the detrimental effects of cerebral ischemia, when administered both before and up to $90 \mathrm{~min}$ after onset of cerebral ischemia. Moreover, we have shown neuroprotective effects of intravitreous TAT-Bcl- $\mathrm{X}_{\mathrm{L}}$ delivery after ON axotomy [19].

In the current study, we evaluated the local neuroprotective effects of TAT-GDNF after ON transection in mice. ON axotomy provides a powerful tool for studying the molecular mechanisms of de- and regeneration of injured CNS neurons in vivo [for review, see ref. 17, 26]. In the present study, we directly compared for the first time the effects of TAT-mediated delivery of a neuroprotective protein (TAT-GDNF) with that of the native protein (GDNF) in this model system. TAT-GDNF efficiently transduces the RGC layer as shown by immunocytochemical analysis after intraocular injection. Particularly transduction of TAT-GDNF is detected in all layers and quadrants of the retina $48 \mathrm{~h}$ after intravitreal injection of the protein. Since no TAT-GDNF was detected in the retina $72 \mathrm{~h}$ after its injection, administrations were repeated at 3-day intervals after ON axotomy. To specifical- ly separate TAT-GDNF, which included an HA tag, from intrinsic GDNF, an immunocytochemical analysis using HA antibodies was performed. Only in retinas that had received treatment with the recombinant protein was GDNF detected.

Both TAT-GDNF and GDNF promoted survival of RGC after axotomy. However, while protection by GDNF was significant only at the medial radius of the retina $(1 / 2)$, the rescue by TAT-GDNF reached significance in all areas of the retina $(1 / 6,3 / 6,5 / 6)$ (fig. 3$)$. The significantly better rescue rates of TAT-GDNF might be explained by its strong and rapid transduction into all regions and quadrants of the retina, whereas the native protein seemed to be less effective especially in the outer retinal sectors. This could also be confirmed when the number of RGCs which expressed active caspase- 3 were compared among the different groups, where significantly fewer RGCs expressed active caspase- 3 in TAT-GDNFtreated animals.

Thus, the present study illustrates that local application of a therapeutic protein (GDNF) is less effective in preventing apoptotic cell death than local application of the protein-transduction-domain-fused recombinant protein, possibly due to the faster and better tissue transduction of the latter protein. This suggests that, besides its superiority in systemic application modes, TAT proteins may also have superior neuroprotective effects in lesion paradigms, where local applications, e.g. via pumps or stereotactic injections, may be preferred over systemic protein delivery, which may often be associated with severe side effects.

\section{Acknowledgment}

We thank Steven F. Dowdy (San Diego, Calif., USA) for providing the pTAT-HA vector. 


\section{References}

1 Frankel AD, Pabo CO: Cellular uptake of the tat protein from human immunodeficiency virus. Cell 1988;55:1189-1193.

$\checkmark 2$ Nagahara H, Vocero-Akbani AM, Snyder EL, et al: Transduction of full-length TAT fusion proteins into mammalian cells: TAT-p27Kip1 induces cell migration. Nat Med 1998;4:1449_ 1452.

$\checkmark 3$ Beck KD, Valverde J, Alexi T, et al: Mesencephalic dopaminergic neurons protected by GDNF from axotomy-induced degeneration in the adult brain. Nature 1995;373:339-341.

$\checkmark 4$ Hoffer B, Olson L: Treatment strategies for neurodegenerative diseases based on trophic factors and cell transplantation techniques. J Neural Transm Suppl 1997;49:1-10.

$>5$ Liberatore GT, Wong JY, Porritt MJ, Donnan GA, Howells DW: Expression of glial cell linederived neurotrophic factor (GDNF) mRNA following mechanical injury to mouse striatum. Neuroreport 1997;8:3097-3101.

6 Abe K, Hayashi T: Expression of the glial cell line-derived neurotrophic factor gene in rat brain after transient MCA occlusion. Brain Res 1997;776:230-234.

-7 Tang YP, Ma YL, Chao CC, Chen KY, Lee EH: Enhanced glial cell line-derived neurotrophic factor mRNA expression upon (-)deprenyl and melatonin treatments. J Neurosc Res 1998;53:593-604.

$>8$ Klöcker N, Braunling F, Isenmann S, Bähr M: In vivo neurotrophic effects of GDNF on axotomized retinal ganglion cells. Neuroreport 1997;8:3439-3442.

$\checkmark 9$ Koeberle PD, Ball AK: Effects of GDNF on retinal ganglion cell survival following axotomy. Vision Res 1998;38:1505-1515.
10 Abe K, Hayashi T, Itoyama Y: Amelioration of brain edema by topical application of glial cell line-derived neurotrophic factor in reperfused rat brain. Neurosci Lett 1997;231:37-40.

11 Kordower JH, Emborg ME, Bloch J, et al: Neurodegeneration prevented by lentiviral vector delivery of GDNF in primate models of Parkinson's disease. Science 2000;290:767-773.

12 Hermann DM, Kilic E, Kügler S, Isenmann S, Bähr M: Adenovirus-mediated GDNF and CNTF pretreatment protects against striatal injury following transient middle cerebral artery occlusion in mice. Neurobiol Dis 2001;8:655666.

13 Hermann DM, Kilic E, Kügler S, Isenmann S, Bähr M: Adenovirus-mediated glial cell linederived neurotrophic factor (GDNF) expression protects against subsequent cortical cold injury in rats. Neurobiol Dis 2001;8:964-973.

14 Hüll M, Bähr M: Differential regulation of cJUN expression in rat retinal ganglion cells after proximal and distal optic nerve transection. Neurosci Lett 1994;178:39-42.

15 Isenmann S, Wahl C, Krajewski S, Reed JC, Bähr M: Up-regulation of Bax protein in degenerating retinal ganglion cells precedes apoptotic cell death after optic nerve lesion in the rat. Eur J Neurosci 1997;9:1763-1772.

16 Kermer P, Klocker N, Labes M, Bähr M: Inhibition of CPP32-like proteases rescues axotomized retinal ganglion cells from secondary cell death in vivo. J Neurosci 1998;18:4656-4662.

17 Klöcker N, Cellerino A, Bähr M: Free radical scavenging and inhibition of nitric oxide synthase potentiates the neurotrophic effects of brain-derived neurotrophic factor on axotomized retinal ganglion cells in vivo. $\mathrm{J}$ Neurosci 1998;18:1038-1046.
18 Bähr M: Live or let die - Retinal ganglion cell death and survival during development and in the lesioned adult CNS. Trends Neurosci 2000; 23:483-490.

19 Dietz GP, Kilic E, Bähr M: Inhibition of neuronal apoptosis in vitro and in vivo using TATmediated protein transduction. Mol Cell Neurosci 2002;21:29-37.

20 Becker-Hapak M, McAllister SS, Dowdy SF: TAT-mediated protein transduction into mammalian cells. Methods 2001;24:247-256.

21 Dietz GP, Kilic E, Bähr M, Isenmann S: Bcl-2 is not required in retinal ganglion cells surviving optic nerve axotomy. Neuroreport 2001;12: 3353-3356.

22 Isenmann S, Engel S, Gillardon F, Bähr M: Bax antisense oligonucleotides reduce axotomy-induced retinal ganglion cell death in vivo by reduction of Bax protein expression. Cell Death Differ 1999;6:673-682.

23 Eschweiler GW, Bähr M: Flunarizine enhances rat retinal ganglion cell survival after axotomy. J Neurol Sci 1993;116:34-40.

24 Kilic E, Dietz GP, Hermann DM, Bähr M: Intravenous TAT-Bcl-Xl is protective after middle cerebral artery occlusion in mice. Ann Neurol 2002;52:617-622.

25 Kilic U, Kilic E, Dietz GP, Bähr M: Intravenous TAT-gdnf is protective after focal cerebral ischemia in mice. Stroke 2003;34:1304-1310.

26 Kermer P, Klöcker N, Weishaupt JH, Bähr M: Transection of the optic nerve in rats: Studying neuronal death and survival in vivo. Brain Res Brain Res Protoc 2001;7:255-260. 